\title{
Modern Distance Learning Technologies in Higher Education: Introduction Problems
}

\author{
Irina A. Leontyeva ${ }^{1^{*}}$ \\ ${ }^{1}$ Kazan Federal University, Elabuga, Republic of Tatarstan, RUSSIA \\ Received 13 February 2018 • Revised 18 April 2018 • Accepted 22 May 2018
}

\begin{abstract}
In the system of higher education, distance learning through the e-learning courses is becoming the most relevant and widely demanded learning mode over the past decade. This article assesses the introduction of distance-learning principles into the university teaching and learning process in terms of quality. The experiment involved 1.250 students learning at the Kazan Federal University. The survey helped to identify the main barriers to the effective implementation of modern distance learning technologies in the university teaching and learning process: non-readiness of teachers and parents, the lack of necessary skills of applying the computer-based online learning systems, inability to interact with the faculty and teachers, the lack of sufficient academic advisors online. In addition, this article investigates the internal problems: limited resources, unevenly distributed marketing advantages, inappropriate administrative structure and the lack of innovative physical facilities. The paper allows sorting out the indicated problems through the stepwise introduction of a distance learning model that fits any university, regardless of its specialization.
\end{abstract}

Keywords: educational management, distance learning, innovative technologies, models for introducing online education

\section{INTRODUCTION}

As the Internet spreads across all industries, colleges and universities also have looked to online software (Dawson, Bakharia, \& Heathcote, 2009; Fuller, Vician, \& Brown, 2006; Guri-Rosenblit, 2016; Kearsley, 2000). Thus, distance learning gains the popularity every day, significantly expanding the teaching and learning space (Beese, 2014) and allowing the students to learn inter-faculty university programs in depth (Aktaruzzaman \& Plunkett, 2016).

Computer technologies allow exchanging information meaningfully at any distance within the framework of the student-teacher system (Bachmaier, 2011; So \& Brush, 2008). Moreover, this learning mode has many advantages than the traditional mode, as it provides the students with the ability to learn at their own pace and in their own space (Thoms \& Eryilmaz, 2014).

It is pertinent to point out that institutional acceptance of e-learning is reflected by strategic commitment among institutional leaders (Allen \& Seaman, 2017). These strategic goals give credence to planning and financial support for distance education (Zawacki-Richter \& Anderson, 2014).

In modern educational environment, success of distance learning largely depends on the perception of teachers. Many of them are questioning the effectiveness of online education and refer to time factors and technical problems (Anderson \& Dron, 2011; Hung, 2016). However, it should be taken into account that modern needs of online teachers have to include the appropriate financial support, limited workload and regular assessment of the online aducation quality (Meyer \& Barefield, 2010). Teachers' feeling about the transition to distance learning will remain insufficient without fulfilling these needs.

In order to expand mutual interaction, distance-learning systems should take into account not only the cognitive and behavioral components (Chow \& Croxton, 2017), but also the social factors (Joksimović et al., 2015; Keller, Ucar, \& Kumtepe, 2017; Liaw, Huang, \& Chen, 2007). However, most campus universities are not ready to teach non-

(C) 2018 by the authors; licensee Modestum Ltd., UK. This article is an open access article distributed under the terms and conditions of the Creative Commons Attribution License (http://creativecommons.org/licenses/by/4.0/). 


\section{Contribution of this paper to the literature}

- The paper provides the most optimal and universal model of online education, deigned to eliminate the identified problems.

- $\quad$ The introduced system meets the principles of student-centered learning and helps to increase the student and teacher's interest in designing a comprehensive distance learning system.

Table 1. Content of questionnaire

\section{№ Question}

1. Do you enjoy working in an online environment? Why?

2. Describe the main advantages and disadvantages of distance learning.

3. How do teachers of your University regard online education?

4. What do you know about the e-learning courses offered in the University?

5. What, in your opinion, are the main obstacles to full implementation of the distance learning principles in your University?

traditional students on a massive scale from the perspective of institutional ethos, culture, structure and administration (Xiao, 2018).

One can note that despite the fact that discourse touching the distance education is popular, Russian e-learning market has many institutional barriers. Even in an academic environment, branding is crucial (Drori, 2015). Therefore, large universities will have a greater competitive advantage by positioning themselves as experts in creating training materials of required quality. They will also be more competitive due to the economic benefits of the reached coverage. The capital universities are promoting their educational services in the regions more often by opening branches and representative offices. This forces regional universities to focus on more innovative learning principles.

Thus, the purpose of this research is to assess the quality of the e-learning system implementation. The research was conducted at Kazan Federal University to define barriers to efficient implementation of distance learning technologies and to introduce a new model, which will have a positive effect on the e-learning development in high school.

\section{METHOD}

Currently, distance-learning courses are being actively designed by teachers of the Elabuga Institute of the Kazan Federal University and are widely introduced into the teaching and learning process. Electronic learning courses were designed through MOODLE LMS for Life Safety, Vertebrate Zoology, Structural Botany, Phytocenology and Molecular biology on the KFU Distance Learning Site (Faculty of Natural \& Mathematical Sciences) (Kazan Federal University, 2018). Such courses are open and accessible for full-time bachelor (undergraduate) students of various pedagogical directions and specialization.

The quality of the e-learning system introduction into the university teaching and learning process will be assessed through the analysis of the experience in using e-learning courses for teaching bachelors, most significantly the Pedagogical Education bachelors. The research involved 1250 students of age between 20 and 22 from 12 departments of Kazan Federal University. There were $41.04 \%$ of male (513) and $58.96 \%$ of female students (737). The majority of participants were the third-year students - $894(71,52 \%)$.

Since distance education is currently highly relevant, it is carried out in full scope in the Elabuga Institute. Every university teacher is designing e-learning resources that are widely applied with traditional modes (KFU Distance Learning Site). The students subscribe for these courses without fail and are trained under strict regulation.

Data were collected between November 2017 and January 2018. Written permissions from the respondents to use their personal data allowed us to conduct a survey and analyze its results. None refused to take part in the survey. The statistical error was $2 \%$.

At the first stage, testing was to determine the main problems and concerns of students about the online learning. The questionnaire consisted of five questions.

The questionnaire structure is presented in Table $\mathbf{1 .}$

Data were collected and then placed into a database to track and organize the information. The number of relevant forms after the survey was 1238. Quantitative data were interpreted using descriptive analysis.

Based on questionnaire analysis and the study of the teaching and learning process quality, the main problems of introducing the distance learning principles were identified. Our original system was designed to eliminate the identified barriers. 
Models for introducing distance learning into the learning process were built according to the CAPDM methodology that helps universities and other learning providers to design and manage the world-class programs of online distance learning (CAPDM, 2007). Besides, it is based on the theory of distance learning introduced by Moore and Kearsley (2011).

Thus, three blocks of distance learning have been tested. Learning approach was shaped according to P-3 Model - learning process included 8-week courses with eight learning modules (Anderson \& Gualco, 2016). The experiment involved students handling the online curricular materials individually and under the guidance of a teacher. Learning tools were the email, content material, discussion forums, video conferencing solutions, online tests and the learning management system Moodle ${ }^{\mathrm{TM}}$. The latter software is an open source project with no licensing costs.

University administration made structural changes to improve program quality and education service, and to ensure program success. Thus, there was established a special subdivision responsible for orchestrating and managing the principles of distance learning. The subdivision has 2 representatives of university administration and 2 students in staff for each faculty, who performed the university's research and organizational activities at high scores. There were allocated teachers responsible for the high-quality implementation of the introduced system in each separate structural unit of the university $(n=24$, two teachers for each faculty). Subdivision members had regular meetings on the problem issues and options for future performance. Moreover, additional wireless laptops were made available to increase the access to computers for students.

\section{RESULTS AND DISCUSSION}

A survey was to identify students' attitudes toward distance learning. We have asked the students whether they like to learn using online courses and $90 \%$ of respondents answered positively, arguing that they can learn the subject at any time (within the limits for learning the unit). It should be noted that distance learning requires the students to be highly independent, but the results showed that not all students were ready to work independently.

Almost all the students (95.6\%) have positively assessed the effectiveness of using distance e-courses. They noted that the advantage of such training is that there is a wide opportunity to learn the material and perform assignments in any place and at any free time. Students noted a wide variety of assessment materials worked out in the electronic courses: tests and problems, creative assignments or case studies, group projects on-line, essays, interactive lectures, hyperlinks, group chat, forum. In addition, students noted that the electronic course is enriched with a large amount of reference information in the form of links to specific sites, electronic textbooks, video materials, etc. This aspect is very important for learning the course.

As for the quality of distance learning, students have highlighted both its advantages and disadvantages: $85.14 \%$ of students noted the availability of distance learning as its advantage. One can learn any electronic course anywhere with any electronic device with Internet access. As it turned out, the psychological aspect of learning with a distance course is also important for a student. At this point, $57.01 \%$ of respondents experienced a decrease in anxiety when performing control tasks (for example, tests, credit-tests).

Besides, recorded answers indicate that distance courses contribute to the development of independent activity skills. The student can independently define how many time he/she needs to go through the same module and/or course unit.

The students have pointed out to the possibility of communicating not only with the teacher (student-teacher interaction) during such courses, but also among themselves (student-student interaction) throughout the period of learning the course.

The main shortcomings of distance learning are the lack of full-fledged communication with teachers and fellow students (about 44\% - 541 students), the lack of skills required for handling the computer-based online learning systems (57.9\% - 712 respondents) and the critical attitude of parents to such type of activity $(39.7 \%-488$ respondents). As for the positive aspects, almost all the participants have pointed out to an opportunity to expand their own space $(89.7 \%$ - 1103) and save their free time $(80.9 \%$ - 995 students).

The analysis of answers has also revealed that the most common concerns regarding the distance education are the concerns about the inability to interact with the faculty and teachers (55.3\% - 680 students) and inability to seek help if it is needed ( $35.8 \%-440$ students). Thus, respondents also indicated the lack of sufficient academic advisors online ( $25.8 \%$ - 292 students). Less than one percent of respondents ( 3 persons) wrote that their academic group size is not appropriate for online learning.

It is pertinent to point out that students with the highest level of confidence face significantly fewer obstacles to social interaction and various administrative issues while using online learning technologies.

Despite the fact that students are well aware of online learning opportunities, only half of them (623 students $50.65 \%$ ) were able to name the specific e-learning courses designed for areas that already run in the University. 
At the same time, $84.00 \%$ of respondents believe that the process of introducing distance learning into the teaching and learning process is just beginning in the higher educational institutions, while $16.00 \%$ note that distance-learning technologies are applied at a high level. This suggests that, currently, distance learning potential has not been fully realized to increase the competitiveness of universities. Many teachers still intent to implement the traditional teaching mode, because they believe that it takes quite a lot of time to prepare this course. On the other hand, the lack of material compensation reduces the interest of teachers in using the problem-developing tasks. This, in turn, reduces the effectiveness of distance learning. The majority of teachers $(78.06 \%)$ called for the combination of distance with full-time modes.

We have asked what electronic courses are taught at the university and the majority of students (79.6\%) named those they had taken starting from the first year of learning at the university. Both compulsory and elective courses were included in the list of electronic courses. At this point, $16.05 \%$ of respondents named courses that they did not take, but learned about them from the university website; $3.09 \%$ of respondents found it difficult to answer.

As soon as the obstacles of distance learning introduction were identified, the internal barriers should be analyzes and assessed carefully. Therefore, the first internal problem that needs to be solved is an incorrect assessment of the university's potential. As the strategic goals are set, university administration has to assess the opportunities, namely - to see how all types of distance learning contribute to the goal achievement. This means that the project is assessed on all items, including costs, financial and non-financial benefits, and the payback factor.

Even if external factors are ignored, it is necessary to determine the market potential of the university, to estimate the sales of education services, to calculate the costs and to forecast the effectiveness throughout the distance-learning project realization. In this regard, distance-learning principles can be introduced into the university teaching and learning process in different ways.

Based on the analysis of these models, we came to the conclusion that at this stage of modern education development it is expedient to apply a mixed training model combining the elements of distance education with the traditional learning process in different proportions. This model is widely applied in the higher educational establishments at the present stage of the social development. However, it looks like the full-time mode is going to be replaced with the distance learning almost completely. Therefore, distance education should be supplemented by direct contacts with highly qualified teachers, who have related skills, as well as with practitioners, who have practical experience in the specified field. Thus, let us consider the 3 proposed models (Figure 1).

Thus, models 2 and 3 can be applied for radical changes in an educational establishment, while model 1, in fact, is an independent approach that will not completely contribute to changes, but will contribute to a quick and economically profitable entrance to a new market. This indicates that the educational establishment is a strategic object for distance learning and a vision of what we want to achieve in this area of activity.

It should be noted that one cannot ignore the distance learning introduction as the internal characteristics of the establishment on the way of entry into this field of activity. The education market structure and competition are the main factors contributing to the success/failure of the educational establishment, but not its internal characteristics and potential.

Since distance learning is being improved and supported by technical innovations and infrastructure, it is necessary to have a support staff and an established structural system for successful entrance to the distance education market. In the higher educational establishments, technological infrastructure is usually not developed at a sufficiently high level, while the required internal skills are also low. Nevertheless, the establishment has to analyze the possibilities, capacity and accessibility of the technological infrastructure before making a decision to design a distance-learning program.

All the elements of technological infrastructure, including the administrative support and the elements of production cycle and learning material presentation, must correspond to the state standards. This infrastructure is of strategic importance, as teaching materials are being converted into high-quality distance learning data. There are two problem areas in this perspective: writing the learning materials in accordance with the standards and in the appropriate form; converting the prepared material into a form that will allow the students to learn at any time and take advantage of learnt material in any situation.

Thus, unlike the full-time mode, distance learning allows realizing the potential of technological infrastructure in such a way that it would be possible to provide the most intense educational experience. For example, test questions do not have to be expanded as educational material because of the on-line mode. Therefore, it is necessary to create measures to update and maintain the technical resources in the operating mode. Besides, IT system in distance education is effective due to the availability of a backup system that is constantly monitored, most significantly if students are learning in different time zones.

One can note that teachers from different countries and universities use Moodle to place notes, videos and try to give students an understanding of content and tasks of different learning subjects (Chavan \& Pavri, 2004; Vargas et al., 2016). 


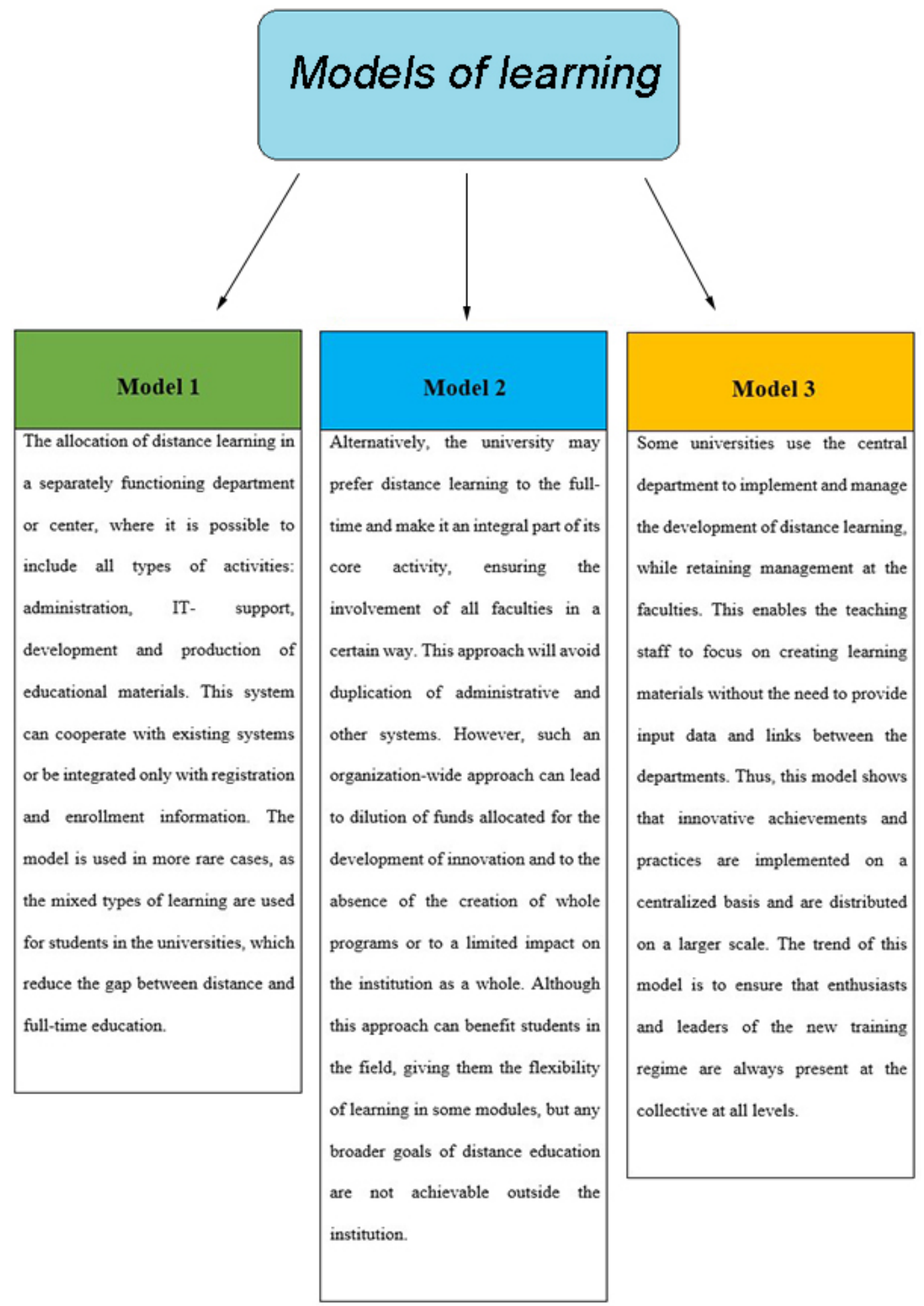

Figure 1. Introduced models of learning

The P-3 Model we applied has already demonstrated the ability to provide the highest possible level of instruction to students. Thus, the number of students taking at least one online course has increased to 6.7 million in USA in 2013 (Allen \& Seaman, 2013). At this point, the Pew Research Center found that while 77\% of American college presidents reported that their institutions offered online courses, only $50 \%$ of them agreed that these courses were at the same level as traditional classroom lessons (Parker, Lenhart, \& Moore, 2011). 
Institutional acceptance of distance learning is important for multi-national and developing societies. For example, the waist majority of teaching materials in Kyrgyz Republic is in Russian language. High and unsustainable cost of printed materials is a problem for book supply (Nurakun Kyzy, Ismailova \& Dündar, 2018). Our research findings are in line with the studies conducted in Iran and Taiwan (Cheng, 2012; Mohammadi, 2015).

Distance education develops through the targets set to improve the power, speed, and accessibility of instructional technologies (Conde et al., 2014; Shannon \& Rice, 2017). Unfortunately, computer literacy remains quite low among students for full-fledged systems application (Hatlevik, Throndsen, Loi, \& Gudmundsdottir, 2018; Hoffman \& Vance, 2005).

Legitimate distance education continues to be the fastest growth area within high education (Reese, 2015). However, there are still some institutional and financial obstacles to holistic implementation of a distance learning framework, such as shortage of skilled teachers (Baran, Correia \& Thompson, 2011) and the lack of technical equipment (Rogerson-Revell, 2015) and poor government support (Piña, 2010).

\section{CONCLUSIONS}

To sum up, distance learning has great potential to set a high standard for valuable learning experiences in virtual environments. The research involved 1.250 second-third-year students. The experiment has revealed that students hold out for online learning, but there are concerns about the quality of interaction with teachers and the undeveloped technological infrastructure of the university. Thus, we have identified internal and external factors that hold back the implementation of modern distance learning technologies, such as limited scope and range of implementation; the problem of resources control; incorrect evaluation of marketing advantages; limited resources, inappropriate administrative structure, etc. The prospects for further research are centered on the assessment of students' knowledge and abilities during the next six months after the introduction of our program.

\section{ACKNOWLEDGEMENTS}

The work is performed according to the Russian Government Program of Competitive Growth of Kazan Federal University (MSRN: 1021602841391).

\section{REFERENCES}

Aktaruzzaman, M., \& Plunkett, M. (2016). An Innovative Approach toward a Comprehensive Distance Education Framework for a Developing Country. American Journal of Distance Education, 30(4), 211-224. https:/ / doi.org/10.1080/08923647.2016.1227098

Allen, I. E., \& Seaman, J. (2013). Changing course: Ten years of tracking online education in the United States. Sloan Consortium. PO Box 1238, Newburyport, MA 01950.

Allen, I. E., \& Seaman, J. (2017). Digital Compass Learning: Distance Education Enrollment Report 2017. Babson Survey Research Group.

Anderson, N. B., \& Gualco, D. (2016). Design of Distance Learning Systems Using a P-3 Model: Purposeful, Participatory and Project-Based. In EdMedia: World Conference on Educational Media and Technology (pp. 493497). Association for the Advancement of Computing in Education (AACE).

Anderson, T., \& Dron, J. (2011). Three generations of distance education pedagogy. The International Review of Research in Open and Distributed Learning, 12(3), 80-97. https:/ / doi.org/10.19173/irrodl.v12i3.890

Bachmaier, R. (2011). Fortbildung Online. Entwicklung, Erprobung und Evaluation eines tutoriell betreuten OnlineSelbstlernangebots für Lehrkräfte (Doctoral dissertation).

Baran, E., Correia, A. P., \& Thompson, A. (2011). Transforming online teaching practice: Critical analysis of the literature on the roles and competencies of online teachers. Distance Education, 32(3), 421-439. https:/ / doi.org/10.1080/01587919.2011.610293

Beese, J. (2014). Expanding learning opportunities for high school students with distance learning. American Journal of Distance Education, 28(4), 292-306. https:/ / doi.org/10.1080/08923647.2014.959343

CAPDM. (2007). An introduction to distance learning: Universities, colleges and distance learning: objectives, strategies and surmounting the barriers, A paper for tertiary education providers. Retrieved on 21 January 2018 from https:/ / www.capdm.com/wp-content/uploads/2017/01/Universities-colleges-and-distance-learningobjectives-strategies-and-surmounting-the-barriers.pdf

Chavan, A., \& Pavri, S. (2004). Open-source learning management with Moodle. Linux Journal, 2004(128), 2.

Cheng, Y. M. (2012). Effects of quality antecedents on e-learning acceptance. Internet Research, 22(3), 361-390. https:/ / doi.org/10.1108/10662241211235699 
Chow, A. S., \& Croxton, R. A. (2017). Designing a Responsive e-Learning Infrastructure: Systemic Change in Higher Education. American Journal of Distance Education, 31(1), 20-42. https:/ / doi.org/10.1080/08923647.2017.1262733

Conde, M. Á., García-Peñalvo, F. J., Rodríguez-Conde, M. J., Alier, M., Casany, M. J., \& Piguillem, J. (2014). An evolving Learning Management System for new educational environments using 2.0 tools. Interactive Learning Environments, 22(2), 188-204. https:/ / doi.org/10.1080/10494820.2012.745433

Dawson, S. P., Bakharia, A., \& Heathcote, E. (2009). Social networks adapting pedagogical practice: SNAPP.

Drori, G. (2015). Branding universities: Trends and strategies. International Higher Education, (71), 3-5. https:/ / doi.org/10.6017/ihe.2013.71.6083

Fuller, R. M., Vician, C., \& Brown, S. A (2006). E-learning and individual characteristics: the role of computer anxiety and communication apprehension. The Journal of Computer Information Systems, 46(4), 103-15.

Guri-Rosenblit, S. (2016). Distance higher education in the digital era: Challenges and prospects. Distance Education in China, 6, 16-25.

Hatlevik, O. E., Throndsen, I., Loi, M., \& Gudmundsdottir, G. B. (2018). Students' ICT self-efficacy and computer and information literacy: Determinants and relationships. Computers $\mathcal{E}$ Education, 118, 107-119. https://doi.org/10.1016/j.compedu.2017.11.011

Hoffman, M. E., \& Vance, D. R. (2005, February). Computer literacy: what students know and from whom they learned it. In ACM SIGCSE Bulletin, 37(1), 356-360.

Hung, M. L. (2016). Teacher readiness for online learning: Scale development and teacher perceptions. Computers E Education, 94, 120-133. https:/ / doi.org/10.1016/j.compedu.2015.11.012

Joksimović, S., Gašević, D., Loughin, T. M., Kovanović, V., \& Hatala, M. (2015). Learning at distance: Effects of interaction traces on academic achievement. Computers $\mathcal{E}$ Education, 87, 204-217. https:/ / doi.org/10.1016/j.compedu.2015.07.002

Kazan Federal University. (2018). The site of distance education of Kazan Federal University. Retrieved on 20 March 2018 from http:/ / edu.kpfu.ru/

Kearsley, G. (2000). Online education: Learning and teaching in cyberspace. Wadsworth Publishing Company.

Keller, J. M., Ucar, H., \& Kumtepe, A. T. (2017). Culture and Motivation in Globalized Open and Distance Learning Spaces. Supporting Multiculturalism in Open and Distance Learning Spaces, 146.

Liaw, S., Huang, H., \& Chen, G. (2007). Surveying instructor and learner attitudes. Computers $\mathcal{E}$ Education, 49(1), 1066-1080. https:// doi.org/10.1016/j.compedu.2006.01.001

Meyer, J. D., \& Barefield, A. C. (2010). Infrastructure and administrative support for online programs. Online Journal of Distance Learning Administration, 13(3), n3.

Mohammadi, H. (2015). Investigating users' perspectives on e-learning: An integration of TAM and IS success model. Computers in Human Behavior, 45, 359-374. https:/ / doi.org/10.1016/j.chb.2014.07.044

Moore, M. G., \& Kearsley, G. (2011). Distance education: A systems view of online learning. Cengage Learning.

Nurakun Kyzy, Z., Ismailova, R., \& Dündar, H. (2018). Learning management system implementation: a case study in the Kyrgyz Republic. Interactive Learning Environments, 1-13. https:/ / doi.org/10.1080/10494820.2018.1427115

Parker, K., Lenhart, A., \& Moore, K. (2011). The digital revolution and higher education: College presidents, public differ on value of online learning. Washington, D.C.: Pew Research Center.

Piña, A. A. (2010). Online diploma mills: Implications for legitimate distance education. Distance Education, 31(1), 121-126. https:// doi.org/10.1080/01587911003725063

Reese, S. A. (2015). Online learning environments in higher education: Connectivism vs. dissociation. Education and information technologies, 20(3), 579-588. https:// doi.org/10.1007/s10639-013-9303-7

Rogerson-Revell, P. (2015). Constructively aligning technologies with learning and assessment in a distance education master's programme. Distance Education, 36(1), 129-147. https:/ / doi.org/10.1080/01587919.2015.1019972

Shannon, L. J. Y., \& Rice, M. (2017). Scoring the Open Source Learning Management Systems. International Journal of Information and Education Technology, 7(6), 432-436.

So, H. J., \& Brush, T. A. (2008). Student perceptions of collaborative learning, social presence and satisfaction in a blended learning environment: Relationships and critical factors. Computers $\mathcal{E}$ education, 51(1), 318-336. https:/ / doi.org/10.1016/j.compedu.2007.05.009 
Thoms, B., \& Eryilmaz, E. (2014). How media choice affects learner interactions in distance learning classes. Computers E Education, 75, 112-126. https:/ / doi.org/10.1016/j.compedu.2014.02.002

Vargas, Y. H., Solís, I. I., Espinosa, J. C. M., \& Olivares, F. M. (2016). Distance Learning vs on Site Learning “A Comparative Study in a Public University in Mexico". Education, 6(3), 69-74. https:/ / doi.rg/10.5923/j.edu.20160603.01

Xiao, J. (2018). On the margins or at the center? Distance education in higher education. Distance Education, 259-274. https://doi.org/10.1080/01587919.2018.1429213

Zawacki-Richter, O., \& Anderson, T. (Eds.). (2014). Online distance education: Towards a research agenda. Athabasca University Press.

\section{http://www.ejmste.com}

